\title{
Reclaiming Home in Indigenous Women Poetry of North America
}

\section{Marija Krivokapić}

University of Montenegro

\begin{abstract}
The tendency of reclaiming home in Indigenous women poetry of North America is seen as a part of a multilayered decolonizing project, which aims at disclosing, reconstructing, and removing the effects of the colonial policy for selfdetermination and betterment of the Indigenous peoples. A precondition of reclaiming home is resurrecting tribal knowledge of belonging which situates the Indigenous subject within family and tribe and close connection to natural surroundings. This paper extends the boundaries of the concept of home from a physical space, such as house and homeland, to a representational one, such as community or cultural articulation, in which one finds comfortable identification (cf. Lefebvre 1991). This assumption supports the expansion of Indigenous agency to the realization of home on the global level. The paper takes a multidisciplinary approach and gathers a vast corpus of poetry, coming from different nations Indigenous to North America, and, therefore, from different locations and writing styles. While using the concept of the Indigenous to refer to Native Americans, Alaskans, First Nations, and Chicanalo, I will also briefly introduce the authors' tribal affiliations to underline the collective pattern of suffering among the diverse groups.
\end{abstract}

Keywords: Indigenous, women poetry, home, decolonization.

\section{Introduction}

The poetry about home authored by women Indigenous to North America reflects the disturbing experience of being deprived of home and, thus, rendered vulnerable to the shifting spaces and identities. Claiming priority over their homes, Indigenous poets work towards disclosing, reconstructing, and removing the effects of colonialism and deal with the series of political, geographical, social, and cultural structures imposed upon the Indigenous subject. While it vitally partakes in a multilayered decolonizing project 
developing around the continent, this poetry also empowers the Indigenous peoples worldwide to join forces in fighting for their social and political rights.

Addressing contemporary hypermobility, critics ${ }^{1}$ argue that home has lost its centrality in life as an embodiment of its dwellers and their culture. They remind of Heidegger's fear that it has become impossible for modernity to dwell because of its alienation produced essentially by technology ${ }^{2}$. However, enforced deprivation of home, as a space of cultural comfort and intimacy necessary for the accumulation of confidence, in which we learn how to respond to physical sensations and social constraints, has led the underprivileged to instability, disorientation, and alienation. Therefore, rebuilding the concept of home is necessary for Indigenous health. As Donald L. Fixico (Shawnee, Sac and Fox, and South-Eastern origin) asserts, home is the Indigenous "strongest point of reference [...] it renders to us a sense of balance and identity." Similarly, First Nations writers Lee Maracle (Stó:lō) and Sandra Laronde (Anishinaabe) insist that home "shapes our governance of the way we engage the world [...] In our beginnings are the processes which speak to how we do things; they define culture." "Thus, reclaiming home necessitates confronting the dominant discourse and recovering Indigenous epistemologies ${ }^{5}$ as equally valid and sustainable.

Being often forced to move, Indigenous peoples inevitably conceive home as inhomogeneous. Home is understood as a physical space, ranging from a house, over homeland, to the Mother Earth, and, to use Henri Lefebvre's term, as a representational space, ${ }^{6}$ such as family, body, language, literature, art, or any other phenomenon in which one finds comfortable identification. Home is also an all-inclusive concept originating in the Indigenous holistic and circular cosmogony that understands connections between physical,

1 Cf. David Morley, Home Territories: Media, Mobility and Identity (London-New York: Routledge, 2000), Gerry Smyth and Jo Croft, eds. Our House: The Representation of Domestic Space in Modern Culture (Amsterdam-New York: Rodopi, 2006), Marit J. MacArthur, The American Landscape in the Poetry of Frost, Bishop, and Ashbery: The House Abandoned (New York: Palgrave MacMillan, 2008).

2 Martin Heidegger, Being and Time, 1927.

3 Donald L. Fixico, ,American Indian History and Writing from Home: Constructing an Indian Perspective,“ Working from Home in American Indian History, ed. Susan M. Hill and Mary Jane Logan McCallum, American Indian Quarterly, 33/4 (2009): 554-55.

4 Lee Maracle and Sandra Laronde, eds., My Home as I Remember (Toronto: Natural Heritage, 2000), i.

5 Cf. Clara Shu-Chun Chang, Writing from Home: Contemporary Native American Women's Life Narrative (National Sun Yat-sen University, Doctoral dissertation, January 2013), 233.

6 Henri Lefebvre, The Production of Space (Oxford: Blackwell, 1991), 33. 
imagined, and abstract phenomena. Home expands from the heart of the house to the universe and from the nucleus family to all one's relations. Understanding home as embracing the whole of one's being and the whole of creation supports indigenous agency not only on a local level, in the house and within the immediate community, but also on a transnational and the global level.

\section{Reclaiming belonging}

Unlike the Western tendency to leave home and realize one's individuality out of its constraints, the Indigenous concept of "homing in" assumes home's priority for the completeness of one's well-being. However, numerous relocations (enacted by the 1830 Indian Relocation Act and urban relocation program induced after World War II) and enforced social accommodations (such as effected by boarding schools and Housing and Urban Development Program) deprived Indigenous peoples of home, leading to the condition of instability, disorientation, and alienation. This experience begs for cultural reimagining. In her poem "Some Like Indians Endure," Laguna artist Paula Gunn Allen invites: "Because the only home/ is each other/ they've occupied all/ the rest/ colonized it. An idea about ourselves/ is all we own." Therefore, reclaiming home necessitates subversion of the official accounts of the past and recovering tribal epistemologies.

In its decolonizing efforts, contemporary Indigenous literature rejects the role of victim in the dominant history and its reconciliatory narrative, and insists that, as LeAnne Howe (Choctaw) reminds, Indigenous peoples make America, its experience, history, and literature. ${ }^{8}$ Therefore, these efforts have to start with contact. As Michel-Rolph Trouillot argues, being constitutive of both "the West and the whiteness as we know them," the myth of "discovery" founded the historicity of the invaded. To claim the indigenous right to self-determination, it is necessary "to step out of history" and reclaim "control over the means of historical production." 10

7 Gloria Anzaldua, ed., Making Face, Making Soul: Haciendo Caras (San Francisco: Aunt Lute, 1990), 298-301.

8 Cf. LeAnne Howe, Choctalking and Other Realities (San Francisco: Aunt Lute, 2013), kindle edition, loc. 654.

9 Michel-Rolph Trouillot, Silencing the Past: Power and the Production of History (Boston, Massachusetts: Beacon, 2015), 16.

10 Ibid., 140. 
This means that the true postcolonial state would be post-historical, i.e. a state in which the Indigenous thought is emancipated from the official history. This demands the deconstruction of the official accounts of the continent's development which abstract the suffering of the Indigenous, securing them in the past and making irrelevant in contemporary society. In her poem "graduate school first semester: so here I am writing about Indians again," Cheryl Savageau (Abenaki) talks about a text from a history book read in the class. The text describes the Battle of Quebec, but it does not mention the French, while Indians appear twice-as nuisances and noble savages. A student reacts offering her version of history: "this was during/ the French and Indian war/ [...] soon thousands/ of French and Indian people/ would be displaced, sold/ into indentured servitude/ my own family among them." Nevertheless, she is silenced by the unsympathetic teacher who only remarks: "thanks for bringing that up." "In "Apprenticed to Justice" by Kimberly Blaeser (Anishinaabe), the lyrical persona still feels "[t]he weight of ashes/ from burned-out camps." The imagery focuses on the destruction of an Indigenous village and on withering animal hide, which the poem interprets as mythic images on which generations of Americans (including the Indigenous) are brought up, especially with the investments from Hollywood that celebrated the national progress brought on the brutal destruction of Indigenous homes. ${ }^{12}$ These images "rest heavy/ sink deep" in a tribal soul, to which the story of encounters is a "history of loss." "13 In "The Theft Outright," Heid E. Erdrich (Ojibwe) references Woody Guthrie's 1940 song "This Land Is Your Land" that at the time appealed to the political leftist as a call for inclusiveness. However, Erdrich reminds that the American zeal has forgotten that the concepts of "your" and "mine" did not exist on the pre-colonized land, but that "[w]e were the land's before we were./ Or the land was ours before you were a land./ Or this land was our land, it was not your land." After this, she turns around the myth-makers' roles, asking: "What's America, but the legend of Rock ' $n$ ' Roll?"14 In her poem "The First Water is the Body," Natalie Diaz (Latina,

11 https://www.poetryfoundation.org/poems/53923/graduate-school-first-semester-so-here-i-am-writingabout-indians-again (accessed July 31, 2019).

12 Cf. Thomas King, The Inconvenient Indian: A Curious Account of Native People in North America (Toronto: Random House, 2012).

$13 \mathrm{https}$ //www.poets.org/poetsorg/poem/apprenticed-justice (accessed September 20, 2018).

14 https://www.poetryfoundation.org/poems/89050/the-theft-outright (accessed May 31, 2018). 
Mojave) explains that the name of her people is Aha Makav which means "the river runs through the middle of our body, the same way it runs through the middle of our land." She supposes that this would be a surrealistic image to an American, but she has "never been true in America" either. America stands for the political, social, and cultural construction whose conventional accounts display reification of the Indigenous into fictional beings and has never recognized this individual's actual reality. Diaz similarly reverses the legend, insisting that, on the contrary, "America is my myth." As a construction, America is a false belief, whereas the river is a living reality that in a circular motion of all the living phenomena makes a part of the speaker's being: "I mean river as a verb. A happening. It's moving/ within me right now." While the river is her true identifier, "thirst" is the word that translates her experience of being devoid of reality. ${ }^{15}$

Linda Tuhiwai Smith (Maori), joins the conversation confirming that indigenous accounts of belonging are "contested," defined as myths in colonizer's theory, because they are differently stored within indigenous systems of knowledge-"within genealogies, within the landscape, within weavings and carvings, even within the personal names." 16 This is why the Western convention of writing, history, and theory often appear intimidating to indigenous students who are unaccustomed to theorizing their existence. ${ }^{17}$ In “Theory Doesn't Live Here” Gwen Nell Westerman (Dakota) argues that her grandparents did not need a theory to understand who they were or "where they came from," because "[t]hey lived it." 18 To show the split between the dominant and the Indigenous thinking, in "Linear Process," Westernman exploits graphical ordering of circles, evoking the tribal way of thinking, juxtaposed to lines, suggestive of the Western linear thought, and empty spaces that recall the fractured knowledge of belonging.

Our elders say

the universe is a

circle.

Everything

returns to its

15 Heid E. Erdrich, ed., New Poets of Native Nations: Twenty-One Poets for the Twenty-Fisrt Century, (Mineapolis, Minnesota: Graywolf, 2018), kindle edition, loc. 1615-1689.

16 Linda Tuhiwai Smith, Decolonizing Methodologies: Research and Indigenous Peoples (London-New York: Zed, University of Otago Press, 2007), 33.

17 Ibid., 29.

18 Erdrich 2018, loc. 1180. 
beginnings.

[...]

Our parents were stripped

of their parents

names tongues

prayers,

lined up for their meals

clothes

classes tests. ${ }^{19}$

Claiming back tribal knowledge requires a proactive rebuilding of protocols and ceremonies that cultivate the indigenous ontologies as potent weapons of emancipation. Indigenous holistic cosmogony understands that humans belong to the universe and that their first relation is that to the Earth, which requires responsible dwelling within a complex net of earthly beings. An abundance of contemporary poetry identifies with this claim. In "I Am of the Earth," Janet Campbell Hale (Coeur d'Alene, Kootenay, Cree) pronounces that the Earth is our mother, who bore and reared us, "built me a house of harmonious colors." Being of the Earth, we are not transitory, because "when I long to leave/ She will embrace me for eternity." ${ }^{20}$ Esselen and Chumash poet Deborah Miranda in her poem "Long Distance" summons that the human body is made of the same six elements as dirt-oxygen, carbon, hydrogen, nitrogen, calcium, and phosphorous - which means that humans are also dirt. This knowledge of primary belonging saves humans from ultimate loneliness: "[ $[$ ] his means if I put my palm/ flat against this soil,/ you will feel my touch/ thousands of miles away./ Thin webs of love stretch/ across a continent: no/ such thing as absence." ${ }^{21}$

Makere Stewart-Harawira (Maori) advocates the development of a "framework for a new eco-humanism that embodies indigenous world views," 22 i.e. "the spiritual reality of existence" and "the oneness of being." ${ }^{23}$ The effective functioning of traditional epistemologies necessitates "re-embedding of traditional spiritually [...] at the centre of indigenous

19 Ibid., loc. 1102.

20 Ibid., loc. 1233.

21 http://badndns.blogspot.com/search?q=this+means+that+we+are+dirt+my+friend (accessed September 22, 2018).

22 Makare Stewart-Harawira, The New Imperial Order: Indigenous Responses to Globalization (AotearoaNew Zealand: Huia, 2005), xiii.

23 Ibid., 250. 
socio-politico-economic and educational endeavours." ${ }^{24}$ It requires a multilayered confrontation to the liberal economy and its "commodification of the lifeworld." ${ }^{25}$ Contemporary authors and critics insist that responsible interaction with all the phenomena makes the core of Indigenous cultures, intellectualism, and activism. Daniel Heath Justice (Cherokee) reasons that Indigenous communities are based on the principle of relations as "a delicate web of rights and responsibilities." ${ }^{26}$ Similarly, Louis Owens (Choctaw, Cherokee) does not find tribal self-determination only in a simple geographical fact, but in the inner social and psychological landscape that embraces, within its stories and memories, the immediate surrounding. ${ }^{27}$ "Such kinship," Heath Justice explains, "isn't a static thing; it's dynamic, ever in motion. It requires attentiveness." 28 That is why "kinship is best thought of as a verb rather than a noun, because kinship, in most indigenous contexts, is something that's done more than something that simply is." 29 This understanding makes the basis for conceptualization of people and nationhood that are not political units but the "constitutive measurement of selfhood." ${ }^{30}$ To explain indigenous ontology, Stewart-Harawira uses the metaphor of "an expanding dialectic spiral, a spiral of transformation that encapsulates the past as constitutive of the present and future and that encompasses the totality of our shared human experience and relationships across all levels of existence." ${ }^{31}$

In line with this prerogative, Chadwick Allen (Chickasaw) emphasizes that " $[t]$ he contemporary Indian writer renders himself coincident with indigenous ancestors and with indigenous history [...] through strategies of narrative re-membering and transgenerational address." 32 Joy Harjo (Muscogee), the current U.S. Poet Laureate, similarly reminds that literature

24 Ibid.

25 Ibid.

26 Daniel Heath Justice, „Go Away, Water!‘ Kinship Criticism and the Decolonization Imperative,“ Reasoning Together: The Native Critics Collective, ed. Craig Womack et al. (Norman: University of Oklahoma Press, 2008), 387.

27 Louis Owens, Mixedblood Messages (Norman: University of Oklahoma Press, 1998), 163.

28 Heath Justice 2008, 150.

29 Ibid.

30 Ibid., 151.

31 Stewart-Harawira 2005, 251.

32 Qt. Andrea M. Modarres, Locating Identities: Narratives of Place in Multiethnic, Immigrant and Diasporic Literature, dissertation (The University of Arizona, 2018), 86. 
"assist[s] in constructing the next world, the next consciousness." 33 Her poem "A Map to the Next World" uses the frame of a South-Eastern creation story about migrations of humans to the sky, ${ }^{34}$ brought on the belief that there is no death, no beginnings and endings, but also that there is no exit from who we are. "What I am telling you is real," says a grandmother to her granddaughter in this poem. Her story is not a fantasy, she says, because it is "printed in a warning on the/ map." Because the idea of the circular existence disallows perpetuity in the materialistic waste, one has to carefully make a new map for this journey by erasing the "killing fields," "the proliferation of supermarkets and malls,/ the altars of money," "artificial lights," and "nuclear anger," because they present "the detour from grace." Unfortunately, the grandmother is afraid that humans have forgotten their origin on earth - "We no longer know the names of the birds here, how to speak to/ them." Abandoning communication with ancestors also frustrates investments in life. Thus, the grandmother advises the child to "smell cooking/ from the encampment where our relatives make a feast of fresh/ deer meat and corn soup, in the Milky Way./ They have never left us." To reimagine relations, people must not re-use the language of abstract thought, but the map must be transient, made "of sand," so that it is refashioned in a continually evolving relationship with it. Finally, this map "can't be read by ordinary light," but has to involve ancestral understanding, i.e. "your mother's voice," to be able to "carry fire to the next tribal town, for renewal of spirit. ${ }^{\prime 35}$ In this way the grandmother invites younger generations to connect with other nations in a joint effort to save Indigenous knowledge.

In her poem "America, I sing you back" Alison Hedge Coke (mixed South-Eastern, Huron, and Metis) develops a conversation with Walt Whitman's "I Hear America Singing" and Langston Hughes, "I, Too," while representing the voice of a woman Indigenous to America. This woman mothered America by singing to it, i.e. by developing a living relationship with it. "Before America began to sing," says the poem, "[m]y song gave her creation, prepared her delivery,/ held her severed cord beautifully beaded."

33 Maya Thau-Eleff, Coming Home: Sovereign Bodies and Sovereign Land in Indigenous Poetry, 19902012, dissertation (Kingstone, Ontario: Queen's University, 2012), 24.

34 Cf. Bill Grantham, Creation Myths and Legends of the Creek Indians (Gainesville: University Press of Florida, 2002), 167-187.

35 https://www.poetryfoundation.org/poems/49621/a-map-to-the-next-world (accessed September 15, 2018). 
Yet this child passes through a turbulent adolescent phase and rejects the mother: "she pushed herself away, forced me to remove myself." Hedge Coke says that the poem was born out of concern because of the politicians' greed and the corruption of the Earth, but also out of a "belief that there is always a way to reclaim beauty." 36 Therefore, this mother knows that the child will mature, so she will patiently wait at the same place: "When she grows far past her self-considered purpose/ I will sing her back, sing her back. I will sing. Oh I will-I do."37

Both poems acknowledge the crucial role of women in Indigenous communities. Namely, a holistic understanding of life disables sexist subordinations in these societies. ${ }^{38}$ The division of gender roles exists, but it is realized, as Patrice E. M. Hollrah argues, through "complementarity, or balanced reciprocity," ${ }^{39}$ which understands that sexes are inclined to different roles but does not ask for the power struggles. ${ }^{40}$ In "Rez Times Three," Susan Beaver (Niibinamik) remembers how she used to sit comfortably at her mother's feet, while her mother was involved in her everyday work, which to her daughter's mind appeared as if she was making "the laws of the universe." They were surrounded by relatives performing their duties: "the old Indian/ aunties make soup down the road/ grammas tell stories in the next house/ uncles split wood in the bush behind our house/ grampas turn soil south of the sugar maples." The poem sees them as "hands/ holding the threads/ of the universe/ together." 41 Thus, home is not experienced as imprisonment and a place of the dissolution of female identity, but as a sacred sphere of female influence. In this basis of health and family's economy, women are nurturers and teachers of cultural knowledge.

Consequently, Indigenous women's poetry cannot be read through feminist tools. Moreover, Hollrah debates, "'white' feminism" is often

36 Bettye Milles, “Allison Hedge Coke and her poem ,America, I Sing You Back“,” November 23, 2016, https://ucrtoday.ucr.edu/42321 (accessed April 27, 2018).

37 Ibid.

38 Patrice E. M. Hollrah, "The Old Lady Trill, the Victory Yell": The Power of Women in Native American Literature (New York-London: Routledge, 2004), 11.

39 Ibid., 6.

40 Ibid. Cf. also Paula Gunn Allen, The Sacred Hoop: Recovering the Feminine in American Indian Traditions (Boston: Beacon, 1992), Elizabeth Cook-Lynn, Why I Can't Read Wallace Stegner and Other Essays: A Tribal Voice (Madison: University of Wisconsin Press, 1996), Devon M. Mihesuah, "Commonality of Difference: American Indian Women and History," American Indian Quarterly, Vol. 20, No. 1 (Winter, 1996): 15-27.

41 Maracle and Laronde 2000,3. 
seen as "another act of colonialism" 42 destructive for the native domestic traditions. Elaborating that modernist sentimentalism was distinctly colonial, Amanda J. Zink analyzes the work of celebrated women novelists (Willa Cather, Edna Ferber, Elinore Cowan Stone, and Evelyn Hunt Raymond) who used the abolitionist agenda to promote the political platform for the rights of white women, while concurrently setting domesticity as "the very definition of American femininity." ${ }^{33}$ This "Manifest Domesticity" 44 could be implemented only through racial uplift, by educating tribal woman, primarily in mission and boarding schools, how to perform this ideal, ${ }^{45}$ not only by recreating the Victorian household but more importantly by being good handmaids in it. This, Leah Maia Sneider elaborates, would mean internalizing patriarchy within tribal communities. ${ }^{46}$ To subvert this project, Native women accept official education, while adapting it to the ancestral domestic rituals. Thus, "You Will Go to School," by Briceida Cuevas Cob (Maya), claims that true knowledge of one's race is first gained at home and in the community of women-"within the cupped hands of your understanding/ you will hold the flow from the womb of the women of/ your race." ${ }^{\prime 7}$ Yet, the young girl is advised to get a formal education to "cross the threshold of [her] imagination," 48 which assumes openness for differences. Acquiring Western education is also indispensable as a means of self-affirmation in the dominant society, against the "dehumanization and marginalizing who we are, ${ }^{49}$ Winona LaDuke (Ojibwe) reminds. The acquired knowledge should always be brought back "to your kitchen,/ to paint the metate's belly with achiote," 50 i.e. to help perform activities that enable cultural continuity.

42 Hollrah 2004, 20.

43 Amanda J. Zink, Fictions of American Domesticity: Indigenous Women, White Women, and the Nation, 1850-1950, dissertation (Urbana, Illinois: University of Illinois at Urbana-Champaign, 2013), 2.

44 Ibid.

45 Ibid., 7-10.

46 Cf. Leah Maia Sneider, Decolonizing Gender: Indigenous Feminism and Native American Literature, dissertation (Albuquerque: The University of New Mexico, 2010), vi, 14.

47 Manya Wubbold, Linguistic and Cultural Continuity through the Symbolic Representation of the Naj ,House ' in Contemporary Mayan Poetry, dissertation (Vancouver: The University of the British Columbia, 2015), 170-172.

48 Ibid.

49 Winona LaDuke, „Foreword,“ in Andrea Smith, Conquest: Sexual Violence and American Indian Genocide (Durham, NC: Duke University Press, 2015), xvii.

50 Wubbold 2015, 170-172. Metate is an oblong stone on which grain is ground. Achiote is a bright orange dye obtained from seed of tropical fruit. 


\section{Land taken}

The Earth as the primary home is subsequently conceived in the frame of ancestral land, which is a source of defining nationhood, along with "kinship relations, governance structures, economic trading networks and well established yet fluid legal orders." ${ }^{51}$ Unlike the "imperial landscape," which presents formlessness, incongruity, and indescribability of Indigenous habitus, while asking to be made an intelligible "western ethnoscape," ${ }_{52}$ with reduction of the Indigenous and celebration of the civilizer, a tribal place is a deeply spiritualized, storied place, a "land/memory," and a "measure of being." 53 Jace Weaver (Cherokee) insists that the moment of intellectual emancipation from colonialism, i.e. the moment of true postcolonialism, is not to come in future. It has always existed for the Indigenous in connection with the land. Indigenous cultures do not see creation as something that happened in the past, ${ }^{54}$ but something that happens in the present and spatially. "Thus, when Indian tribes were forcibly removed from their homes, they were robbed of more than territory. Taken from them was a numinous world where every mountain and lake hold meaning for their faith and identity." ${ }^{55}$ The land is commemorative of tribal past, as it bears the marks of the past and mythical events, and allows conversation with ancestors. As I explain elsewhere, ${ }^{56}$ drawing from Fixico, Thomas M. Norton-Smith (Shawnee), and Greg Sarris (Coast Miwok), the natural environment receives a status of a sacred persona in the indigenous thought system. Namely, while Fixico argues that "Indian thinking" is visualizing connections between entities,${ }^{57}$ Norton-Smith explains that this visualization does not proceed in a propositional manner, i.e. through possession of facts, but in a procedural, ritual, and a responsible way in which the world is seen as a "creative,

51 Michelle Daigle, ,Awawanenitakik: The spatial politics of recognition and relational geographies of Indigenous self-determination," The Canadian Geographer/ Le Geographe canadien 2016, xx(xx): 1-11, 2.

52 Michael J. Shapiro, Methods and Nations: Cultural Governance and the Indigenous Subject (New YorkLondon: Routledge, 2006), 102-111.

53 Ana Mongibello, ,Tracking the Land/Memory. Healing and Reterritorialization in in Jannette Armstrong 's Breath Tracks,“ Indigenous Perspectives of North America: A Collection of Studies, eds. E. Sepsi et al. (Newcastle: Cambridge Scholars, 2014), 143-159.

54 Cf. Joseph Bauerkemper, „Narrating Nationhood,“ SAIL (Winter 2007, Vol. 19, No. 4), 27-53, 44.

55 Jace Weaver, Other Words: American Indian Literature, Law, and Culture (Norman: University of Oklahoma Press, 2001), 300.

56 Marija Krivokapić Knežević, „Maximum Morality of Art: Thomas King“s Medicine River,“ Where No One Else Has Gone Before, Proceedings of the Ninth Native American Symposium, ed. Mark B. Spenser (Durant, OK: Southeastern Oklahoma State University, 2012), 29-30.

57 Donald L. Fixico, The American Indian Mind in a Linear World (New York-London: Routledge, 2003), 1-2. 
animate, dynamic, purposeful, unfixed, and unfinished." ${ }^{58}$ Responsible communication is a creative act, an instant of possibility, which does not understand the land as an object, but as a person, an amalgam of moral and metaphysical concepts in a network of relations, ${ }^{59}$ which always calls into existence the people living on it and their personal stories. ${ }^{60}$ Thus, the land is intimately familiar to its inhabitants. Confronting someone's assumed right to rename such a place, in "Proclamation," Ofelia Zapeda (Tohono O'odham) says that Tucson is only "a linguistic alternative" of Cuk Son, which "is a story" that recalls "people walking/ deserts all their lives" ${ }^{1}$ and gives shape to the surrounding mountains.

Accordingly, relocation is described as a severe existential rupture. Linda Hogan (Chickasaw), in "Trail of Tears," sees it as a great cut through the being of her nation, a violent reordering of the nation's sacred places. The new political, economic, and geographical lines enforced upon the land cannot be comprehended within the tribal-centered and land-centered system of knowledge. Therefore, the lyrical persona believes that when "[w]ith lines unseen the land was broken," the body of the people was transformed into "measured geography." ${ }^{2}$ In other words, when superficial political borders dissected the sacred land, the tribal reality suffered from an unperceivable reification and material measuring. In "Undivided Interest," Westernman announces that her land, once "called Tiyowaštewin," has turned into an address, "letters and numbers./ Fractions." Westernman refers to the 1887 Dawes Act by which the native land was subdivided into individual allotments. Because the land was understood as a being in vital relationship with the tribe that could not be personally owned, the tribes experienced this measure as most destructive, altering almost irrevocably the sense of place, self, family, and tribe. With the Dawes Commission deciding who was eligible to own the land by the measured blood quantum - which detribalized numerous individuals without enough "Indian" blood - and with the decision that in 25 years from the acquisition of the allotment the new proprietor had to pay the State back for the allotted

58 Thomas Norton-Smith, The Dance of Person and Place (State University of New York: SUNY, 2010), kindle edition, $42 \%$.

59 Ibid., $56 \%$.

60 Greg Sarris, Keeping Slug Woman Alive: A Holistic Approach to American Indian Texts (Berkley-Los Angeles-Oxford: University of California Press, 1993), 40.

61 https://www.poetryfoundation.org/poems/53448/proclamation (accessed June 3, 2018).

62 https://www.poetryfoundation.org/poems/57881/trail-of-tears-our-removal (accessed May 20, 2018). 
land - which demand was difficult to meet because the land originally " given" to the tribes was the least fertile-the amount of tribally owned land gradually shrunk and was sold at a bargain price to non-Natives. Thus, in Westernman's poem, when the "undivided interest-divided/ among 336 heirs," her own "interest equals 0.119 acres." The living existent with a name, the sacred collocutor is now addressed as an economic item, an "interest," and her sole "ancestor" remains "an Indian Account." 63

The loss of land is experienced as the loss of an intimate part of being. In "Land Sickness," Carol Snow Moon Bachofner (Abenaki) experiences the land as her lover and the removal as being "flung away" from the source of identity and health. She is "bereft/ of crisp ocean kisses and wild seaweed,/ dancing like a sultry lover around my ankles." If she dies of her need of "Maine's shore," she will be found petrified, while "[i]n one tight fist will they find a single drop/ of salt, a tear that began in the surf of home." ${ }^{64}$ In "Birthmark," bg Jennifer Foerster (Muscogee), the lyrical persona's grief for the homeland is connected with the loss of the command over her mother tongue, which would enable her to communicate her internalized historical trauma. She said that her "words [are] taken from mouth," referring to the forced abolition of tribal languages and religious practices in boarding schools. She lives in an urban environment and is isolated from a community that would understand and help. Her attempt to communicate with the psychiatrists is frustrated as they keep treating her with medicine that does not heal. Being unable to express her pain, she had to hurt herself by cutting a scar on her ankle. Because she is not simply suicidal, but she carries her nation's pain, the scar becomes a birthmark. She says that she is "[b]orn with it, a stain on the skin." Connoting a dirty mark, this stain also references racial prejudice. However, this particular body color can be claimed as a way of stealing back her homeland and identity, of finding "your own map on the body." Hence, the scar can also be a means of preservation, "a little boat, to me." ${ }^{65}$

Frequent are juxtapositions of images of the past rootedness in the land with those of mechanical uprooting of homes. Foerster's "Leaving Tulsa" recollects wildlife on her land, coyotes, cardinals, frogs, overgrown fields of tomatoes, squash, watermelons, peach trees. She remembers her grandmother teaching how to relate to the land, how "to shuck corn," fish

63 Erdrich 2018, loc. 1195.

64 Maracle and Laronde 2000, 68.

65 Erdrich 2018, loc. 1305-1368. 
for dragonflies, and walk among hay bales looking for turtle shells. While doing this, her grandmother was "laughing," i.e. her teaching was imbued with joy. The poem focuses on a chestnut tree under which the grandmother buried "her bundle of beads. They tell/ the story of our family." The use of italics emphasizes that this story is told in the tribal ceremonial language using beads. There was also a cedar tree whose birch was used for healing, assuming a deep belief in nature's healing power. However, one day, "the bulldozers came/ with their documents from the city/ and a truckload of pipelines," and her grandmother's land was "flattened to a parking lot." The poem now captures devastated houses: "a roof blown off a shed,/ beams bent like matchsticks." ${ }^{66}$ In "How the Milky Way Was Made," Natalie Diaz says that the river of her home, Colorado, once connected with all the rivers across the continent, is now "shattered by fifteen dams/ over onethousand four-hundred and fifty miles,/ pipes and pumps filling/ swimming pools and sprinklers/ in Los Angeles and Las Vegas." ${ }^{67}$ Tribal lands are often exploited for warfare experiments or business enterprises, such as mines and fracking, which pollute land and water. "Reservation," by Diane Glancy (Cherokee), depicts "a carp with a tumor/ on its lip,/larva eating its side" served on their table. It pictures an old man laughing, showing only "one silver tooth," which reminds of "a galvanized/ watertank." 68

In "Warming," Inuit author Dg Nanouk Okpik expresses regret because of the global warming that continually endangers her home, affecting its literal melting. The lyrical persona does not belong alone to this home and cannot claim a story as personal property. As a part of cultural knowledge, every story has to recognize the contribution of others. Weaver defines this understanding as "we-hermeneutic," for which, unlike the monologist "I-hermeneutic," community is not only a tool but the frame, context, and aim of the hermeneutic activity ${ }^{69}$ Thus, this poem cannot take an individual perspective, but describes the process undergone by a "she/I," the mother and the child and, simultaneously, the mother that gave birth to the lyrical persona and the child that this persona will give birth to. English appears inadequate for the activities and the subjects mentioned: "She/I chain stitch/ es a skin dressed in oil to make a new pot of soup," or "She/I eat/s club

66 Ibid., loc. 1206-1260.

67 https://www.poets.org/poetsorg/poem/how-milky-way-was-made (accessed September 24, 2018).

68 https://www.poetryfoundation.org/poems/50883/reservation (accessed June 15, 2018).

69 Cf. Weaver 2001, 300-303. 
root and white clover to strengthen her/my silver/ body to bear a child." Yet, when "She/I want/s" to collect some water, by making "a hole on the surface," supposed to be frozen, they realize that "the/ earth is molding, burning, laughing, and purging its crust." ${ }^{\text {" }}$

Louise Erdrich's "Turtle Mountain Reservation" depicts the dominant culture's destructive influence through images of a neglected family's house with thick dust collecting on the bedroom shade. In it, grandfather "leans back/ between spoonfuls of canned soup," i.e. he does not feed himself in a traditional way, but with the commodity food supplied by the government-it was a long time ago "when from sloughs, the great salamander/ lumbers through snow, salt, and fire/ to be with him." He has lost his sacred function of the storyteller and only "repeats to himself a word/ that belongs to a world/ no one else can remember." The influence of Christianity and alcohol devastate tribal stories: "Uncle Ray, drunk for three days/ behind the jagged window/ of a new government box,/ drapes himself in fallen curtains, and dreams that the odd/ beast [...] crouches moaning at the door to his body." The wind Theresa used to be celebrated because it vividly partakes in the recreation of life - it "smells/ like a hayfield, drifting pollen/ of birch trees." However, now the boys spend their time in bars"The Blazer, The Tomahawk,/The White Roach Bar." Instead of relying on nature's gifts, they count on "the small fortune" from the bingo organized in the mission. ${ }^{71}$

\section{Our House}

Home is understood as the embodiment of its occupiers. Its quality, Lidya Angelova derives, lies in the intangible sense of comfort and belonging, which results from meaningful construction of spaces that understand our bodies and psyche. ${ }^{72}$ An Indigenous house is built respecting ancient ontology and rituals. Black Elk Speaks records the Oglala visionary saying: "Our tepees were round like the nests of birds, and these were always set in a circle, the nation's hoop, the nest of many nests, where the Great Spirit meant for us to hatch our children." ${ }^{, 73}$ Mayan house is also construed to

70 Erdrich 2018, loc. 1893.

71 https://www.poetryfoundation.org/poems/43087/turtle-mountain-reservation (accessed June 15, 2018).

72 Lidya Angelova, Phenomenology of Home, dissertation (Tampa: University of South Florida, 2010), 29.

73 John G. Neihardt, Black Elk Speaks: Being the Life Story of a Holy Man of the Oglala Sioux, as told 
evoke the universe and human experience. It is defined as "the four corners of the universe." 74 It has three conceptual levels: "[t]he heavens, its roof and rafters; [t]he earth, the main floor or general living space [...] [t] he underworld, below the house where artifacts are buried." 75 The house is attended as a living being with a soul. Its roof represents its head, the poles of walls are the house's ribs, "while the main posts anchoring it to the earth are its feet. The house's covering is its skin, its walls are its stomach, its corners are its ears, the door and windows [...] are its eyes and mouth, and its hearth is its heart." ${ }^{\prime 76}$ Similarly, pueblo house represents the female body, with doors standing as an entrance to the uterus. ${ }^{77}$

However, the Euro-American idea of domesticity has a prolonged influence on the indigenous perpetuation of creation through house formation. Not only did the first generation of the residential school graduates start building their houses in the required Victorian style, ${ }^{78}$ but also the "domestic sphere" became a cultural space defined by Euro-American women. ${ }^{79}$ Especially detrimental to the social fabric of native communities are the houses provided by the U.S. Department of Housing and Urban Development (HUD). In "Housing Conditions of One Hundred Fifty Chippewa Families," ${ }^{80}$ Kimberly Blaeser describes the White Earth Reservation of 1938. It had, as counted by "sister hilger," "seventy-one tar-paper shacks,/ eight united states rehabilitation houses/ two wigwams/ bark houses at rice camps." While graphing and measuring dimensions, this outsider also records "23 with broken windows;/ 99 without foundations [...] 98 with stove pipes for chimneys." Nevertheless, she does not understand that what she finds an inappropriate "house, dwelling place, structure," the Chippewa call "home. Endaayaang." The measurements considered compulsory for the missionary purposes are incomprehensible and inessential for the survival of the tribe. Thus, $75 \%$ of the inhabitants of this dilapidated, "sub-sub-

through John G. Neihardt (Albany, BY: State University of New York Press, 2008), 383.

74

75

76

77$$
\text { edi/ }
$$

79 Cf. Zink 2013, 185-187.

Cf. Elizabet Vlaire Kalbleisch, Bordering on feminism: home and transnational sites in recent visual culture and native women's art, doctoral thesis (Rochester: University of Rochester, 2009), 170

80 https://www.poets.org/poetsorg/poem/housing-conditions-one-hundred-fifty-chippewa-families (accessed September 20,2018). 
standard, sub-human" place did not want to move to the proposed "rehabilitation/ house; one of those fine new houses/ the Indian Bureau built for the Indians." The people know the place as "Gaa-waabaabiganikaag," and they live the spirit of its white clay, which no "cautious recollection" and precise "tabulations/ upon white pages" can record.

Once excluded from the mediated public space, as Roberta Hill's "In the Longhouse, Oneida Museum" depicts, the Indigenous house is brought into a museum, among other indigenous arts and crafts, left in the unrecoverable past, and forbidden to touch. The lyrical persona regrets the loss of this "[h]ouse of five fires," which used to home five families, because it "never raised [her]." That her loss is also national shows the idea that as a wanderer, devoid of stable identity and anchor-"as if without a history," i.e. without a possibility to develop stories and relations around her life, "I should always walk/ the cluttered streets of this hapless continent." ${ }^{11}$ The streets are cluttered with material acquisitions and the continent is a place of reified relations.

The new modern HUD "efficiency" kitchens directly endanger the eating area as the center of native hospitality. ${ }^{82}$ Ignoring that meals are occasions for families and groups to gather, as echoed in Joy Harjo's poem "Perhaps the World Ends Here," they make thus the kitchen table surplus. In this poem, Harjo describes the rich family life that revolves around the table, life dramas, stories, memories, and everyday banalities. "The world begins at a kitchen table," she says, because that is where "we" share food. Our babies play around the table; they "teethe at the corners" and "scrape their knees under it." When they grow up, it is around the table that they receive "instructions on what it means to be human," i.e. responsible adults. Families and friends gossip, dream, start and end wars, laugh, sing, and comfort each other at the table, so that " $[\mathrm{t}] \mathrm{his}$ table has been a house in the rain, an umbrella in the sun." Finally, "we have given birth on this table, and have prepared our parents for burial here." Yet, the centrifugal tendency that leads away from this heart affects, for Harjo, the end of humanity. Thus, the house becomes a place of residence and not home.

In "The Housing Poem," by Dian Million (Tanana Athabascan), Minnie has found a job outside the reservation and rented a small house with a

81 https://www.poetryfoundation.org/poems/48654/in-the-longhouse-oneida-museum (accessed May 10, 2018).

82 Cf. Kalbleisch 2009, 170. 
little garden. Minnie likes the kitchen with "a large old cast iron stove." Because of this old piece of furniture "the house was so cheap," i.e. cheap enough for Minnie to rent it. We will place Minnie's story within a larger picture of the Indigenous who were systematically relocated to the urban areas after World War II, as another attempt at their detribalization. The program affected almost $70 \%$ of the Indigenous to leave their reservations, searching for better job opportunities. However, the Bureau of Indian Affairs purposefully channeled the relocatees into substandard housing. Fixico explains that despite the Fair Housing Act of 1968, which ruled out discrimination "'against any person in terms, conditions, or privileges of sale or rental of dwelling, or in the provision of services or facilities in connection therewith,' [...] prejudiced landlords continued to discriminate against Indians," ${ }^{\prime 3}$ especially those with children. They introduced "credit checks, security deposits, and advanced rent" ${ }^{\prime 4}$ which made housing unaffordable or uncomfortable. Most did not complain because they were either unaware of the housing rules, "afraid to complain," or they "accepted that they were expected to live in rundown conditions." 85 In Million's poem the sense of belonging is ceremonially presented through the images of Minnie's family members gradually moving to her place, emphasized by the adverbial phrase "pretty soon" which opens each stanza. Those are Minnie's brother and his wife who soon got a baby, twin cousins who liked to camp in the garden, Minnie's mother "because she liked being with the laughing young people/ and she knew how the stove worked best" - for whom Minnie moved to sleep on a cot-and their grandmother whom they could not leave "in Moose Glen back home," because "they all missed her anyway and her funny stories." Now, there are "Minnie, Rupert and Onna, Sarah and Elsie,/ Shar and Dar/ all singing around the drum next to the big stove in the kitchen/ and even a baby named Lester who smiled waving a big greasy piece/ of dried fish." Undermining in terms of cultural coherence is the sudden appearance of the landlord, who "came by/ to fix the leak in the bathroom pipe" (which accentuates the rundown conditions of the house). Angered by the number of people he encountered, he evicted Minnie, 
arguing that "the house was designed for single-family occupancy." 86 This example shows the federal laws as detrimental to Indigenous understanding of family.

"The Story of My Life" by Carroll Arnett talks about emotional disorders brought by dispossession of a house of one's upbringing. The family house on "Oklahoma red dirt" was lost due to the weakened agency of the tribal government, which allowed her white grandfather to "steal" it from her Cherokee grandmother, drink, and gamble it away. This act determined dispersal of the grandaughter's identity and saw her moving across the States searching for a home. The poem's graphically suggestive structure, with verses transversing the page left and right, accentuate the experience. Having spent life wandering around the country, burdened with alcoholic heritage and the history of violence, she concludes:

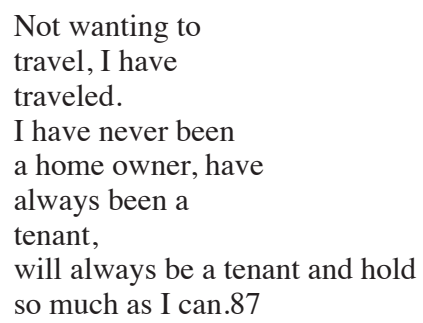

An essential quality of home lies in the perceptive intimacy and comfort which come from ritualistic repetitions of activities performed in it. Compellingly different from this is the traumatic experience in boarding schools that split families apart, hampered every possible privacy, and forbid home, language, and culture. Her poem "Indian Boarding School: The Runaways," Louise Erdrich starts with the line: "Home's the place we head for in our sleep." The children's anxiety in these supposedly educational spaces is so overwhelming that their idea of home comes to them only in an unconscious state. They feel like prisoners who dare not escape because there is always a police officer ready to take the runaways back and punish them. The disciplined behavior works towards instilling a sense of racial guilt, which is emphasized by the image of the highway that takes them back to their enforced residences. When "[t]he highway 
doesn't rock, it only hums/ like a wing of long insults," it does not take the children to a prospective home but sounds like a long insulting whip. Insults are long because they characterize the history of the encounters in which the Indigenous were vilified whenever they claimed their rights. The historical trauma intensifies when these children are beaten. Saying that the "welts/ of ancient punishments" are "worn-down," ${ }^{88}$ does not suggest that the condemnation has abated but that the trauma will be transferred onto the successors. Church has been another unfriendly house. In "On a Catholic Childhood" Janet Campbell Hale (Coeur d'Alene) tells of six-year-old children terrified with the stories of purgatory and forced to say prayers in Spanish, the language they did not speak, while kneeling on hard floors and looking at "a gory/ life-size painted statue of/ the crucified Christ," ${ }^{89}$ which to their cultural eyes evoked neither sacrifice nor beauty.

\section{Representational spaces}

If it is impossible to return home, it is possible to cherish the stories of it, because "our memory [houses] our history." ${ }^{0}$ Thus, the indigenous experience can be compared to diasporic, drawing from James Clifford's definition of diaspora as an expatriate community that, feeling alienated in the host country, actively cherishes the memory of home to support the group's solidarity. ${ }^{91}$ In urban eras, numerous cultural articulations serve maintenance of culture, language, and ceremonies, such as family gatherings, meetings, workshops, powwows, sharing food, because the tribal self is always relational and defined by the community and environment. ${ }^{92}$ In her long prose poem Whereas, Long Soldier (Lakota) clarifies that she has always desired to be a part of a community, "[a] piece combined with others to make up a whole." She illustrates this "participation" with a memory of "a grassy clearing with three tipis, a place to gather," near her aunt's house. Namely, her aunt often held workshops on traditional arts

Alan R. Velie, ed., American Indian Literature: An Anthology (Norman-London: University of Oklahoma Press, 1991), 334.

89 Erdrich 2018, loc. 900.

90 Maracle and Laronde 2000, 1.

91 James Clifford, „Diasporas,“ Cultural Anthropology, Vol. 9, No. 3, Further Inflections: Toward Ethnographies of the Future (Aug., 1994): 302-338., 304-305. http://links.jstor.org/sici?sici=08867356\% 28199408\%299\%3A3\%3C302\%3AD\%3E2.0.CO\%3B2-O) (accessed July 3, 2018).

92 Hertha Dawn Wong, Sending My Heart Back across the Years: Tradition and Innovation of Native American Autobiography (New York: Oxford University Press, 1992), 13. 
to which a lot of young people from the surrounding area came "eager to participate." Although they could commute daily to the workshops, they preferred to "stay and camp even during South Dakota winters," because of "[t]he comfort of being together." 93

Home is also a space dominated and appropriated by the ritualistic use of objects..$^{94}$ Ann Romines elaborates that domestic rituals, be they momentous occasion, such as a wedding, or "an ordinary task such as serving a meal [...] help to preserve the shelter," ${ }^{95}$ i.e. "continuity of a common culture." ${ }^{96}$ Lucy Tapahonso's poem "It has Always Been This Way" shows Navajo home as a social order. In responsible attendance to one's surroundings, everything becomes a ceremony within a circle of relatives. Tapahonso talks about the series of ceremonies that follow the growing up of a child. While carrying the child, the mother attends to the protection of her baby and, thus, she never "go[es] near noisy or evil places./ [...] cut meat or take part in the killing of food." When the baby is born, "[a] pinch of pollen" is placed on its tongue because pollen is good for lungs and general health. When " $[t]$ he belly button dries and falls off./ It is buried near the house so the child/ will always return home and help the mother." When the child is still a baby, the mother takes "[m]uch care [...] to shape the baby's head well/ and to talk and sing to the baby softly in the right way." When the baby becomes aware of its surrounding, i.e. when it "laughs aloud," all the relatives laugh too, making sure they celebrate this moment with "rock salt,/ lots of food [...] Everyone passes the baby around./ This is so the child will always be generous/ [...] surrounded by happiness" and "by lots of relatives." When the child goes to school, more pollen is placed "on top of her head and on her tongue./ This is done so the child will think clearly,/ listen quietly, and learn well." Repetitive rhythmic and syntactic structures of Dine ceremonial language emphasize this order. Thus, every stanza ends with a confirmation: "It has been this way for centuries among us." The last stanza evokes the sacred number four that evokes circularity by summoning: "You are here./ Your parents are here./ Your relatives are here./ We are all here together." ${ }^{97}$

93 Laily Long Soldier, Whereas (Minneapolis, Minnesota: Graywolf, 2012 ), 64.

94 Cf. Lefebvre 1991, 39.

95 Ann Romines, Home Plot: Women, Writing \& Domestic Ritual Account (Amherst: University of Massachusetts Press, 1992), 12.

96 Ibid.

97 http://www.hanksville.org/storytellers/luci/poems/always.html (accessed July 1, 2019). 
Among vital protocols and ceremonies that cultivate indigenous ontologies are those related to food. Roberto Cintli Rodríguez describes narratives about the sacred maíz as the foundational stories of the Indigenous culture, which are crucial for connecting "de-Indigenized and deceremonialized, often dehumanized, peoples [...] to story and place." ${ }^{\circ 8}$ He analyzes the poem "The Elements to Create," by María Molina Vai Sevoi (Yoeme and Nahua Tlalmanalcah), which in ritualistically repetitive language, enlivens the core of the maíz culture and develops on the images of seeds begotten in the dark womb of "Great Mother" that rise in a spiral towards Father Sun. That is when "new generation is born" and "the human being has transcended." 99 This poem, therefore, relates, Rodríguez explains, that this "sacred sustenance [...] permitted human beings [...] to arrive at the concept of time by observing the cyclical nature of the universe" and "to produce advanced, astronomically and mathematically based calendars." However, when devoid of traditional ceremonial ground, new ceremonies can be invented. Although fry bread and the Indian taco come from the federal commodity food issued when the tribes were displaced and disabled from producing their medicine food ${ }^{101}$ they are typical of tribal cultures because they are consumed with families. In "How to make really delicious fry bread," Chrystos (Menominee) advises kneading in a lot of love, joy, and remembrance of those who need prayer, while surrounded by the loved ones, lovemaking, birds singing, and "some strong Indian music." After this, the dough should be shaped "into a round mound," resembling the Earth, crossed in the four directions, and "[c]overed with a clean red bandanna." ${ }^{102}$ A bandanna is also an iconic item in the American culture, which symbolizes self-determination mostly associated with sub-cultures.

However, stereotypical presentations of hundreds of Indigenous cultures, languages, and lifestyles reveal genocide and hypocrisy by reducing Indigenous agency in contemporary life while filling the entertainment industry's budget. LeAnne Howe uses the image of the "noble savage"

98 Roberto Cintli Rodríguez, Our Sacred Maíz Is Our Mother: Nin Tonantzin Non Centeotl: Indigeneity and Belonging in the Americas (Tucson: The University of Arizona Press, 2014), 3-4.

99 Ibid., 128.

100 Ibid., xix.

101 Lois Ellen Frank, The Discourse and Practice of Native American Cuisine: Native American Chefs and Native American Cooks in Contemporary Southwest Kitchens, dissertation (Albuquerque: University of New Mexico, 2011), 105.

102 Maracle and Laronde 2000, 8. 
in its disturbing appearance of the unhomely, i.e. something familiar but lacking the characteristics of friendliness, comfort, and privacy that home provides. This concept is introduced by Freud as unheimlich, "uncanny," 103 and refashioned by Homi Bhabha who refers to the moment when the outside world and the historical occurrences suddenly manifest themselves within the private sphere, becoming a part of the home. Thus, they are both strangely familiar and alarming, as they blur the distinction between home and the outside world. "The home does not remain the domain of domestic life," Bhabha says, "nor does the world simply become its social or historical counterpart. The unhomely is the shock of recognition of the world-inthe-home, the home-in-the-world." 104 Howe's poem "My Name is Noble Savage" describes "noble savage" as "something," not someone, that had to be destroyed to be reinvented and used "[a]s your pet, a mascot," an exotic inspiration. It was thrown out of the colonizer's new house and reinvented as a souvenir of its mythological past. While it carries many wounds from the historical mistreatments ("How many wounds do you hope I carry?"), today this image brazenly displays ignorance that robs the Indigenous of their reality and political rights. To fight this ignorance, Howe ironically readopts this body and addresses its creator-"Since I am your invention/ everything I say is coming true," showing that this mascot is, actually, its creator's mirror, speaking in its creator's words that are granted truth. Yet, it is a frightening truth that reveals itself as a very intimate and unpleasant story: "I am the story you finger-fucked/ the evidence under your fingernail/ Can you feel me coming for you?" In "Indian Mascot Encounters Prejudice (from Real Indians)," Howe explains that real people must hate this invention because "He's white [...] He's a bestial impersonator." 105

As a representational space, home can be reterritorialized in poetry as a space of affirmation. In "Missing More Than a Word," Tanaya Winder (Shoshone) reminds that racial injustice involves sexual abuse ${ }^{106}$ and that "I in 3 Native women will be raped in her lifetime." The statistics of the unsolved cases of missing, raped, or killed Indigenous women are disturbing,

103 Cf. Sigmund Freud, "The Uncanny," 1919. https://web.mit.edu/allanmc/www/freud1.pdf (accessed January 22, 2020).

104 Homi Bhabha, "The World and the Home," Social Text 31/32 (1992), 141.

105 Elizabeth Tool, „Noble Savage and Indian Mascot by LeAnne Howe,“ https://elizabethtool.wordpress. com/tag/leanne-howe/ (accessed April 20,2018).

106 Cf. Smith 2015. 
mainly because for the law officials these cases are mostly "underreported," i.e. without enough evidence to make the cause. Winder reverses data to point to the discrepancy in the work of the police: "A recent government study found that there were 14 federal human/ trafficking investigations in Indian Country between 2013 and/ 2016. During that same period the FBI investigated 6,100/ elsewhere." Lacking enough words to "story our bodies in something more/ than missing," she invites: "Let us poem a place where you cannot erase us into white space."107

As a container of memories and words, H. E. Erdrich says, contemporary Indigenous poetry builds up a destination that "feels like a familiar country." 108 We cannot avoid asking if the wanted reinvention is possible within the constraints of the dominant discursive parameters and its print culture. Agreeing with L.T. Smith that the ability to name things in one language is an important confirmation of one's reality, Jane Staffort adds that "[f]or communities there are realities which can only be found in the indigenous language; the concepts which are self-evident in the indigenous language can never be captured by another language." 109 In "Casualties," M. L. Smoker (Assiniboine, Sioux) shows regret for losing language by leaving blank spaces where important names or modifiers should stand.

Still as I tell of stillness

of a very word

as ( $\quad$ ) as it leaves this world

She misses the right words for her body parts, so they are also gone: "where hands/ belong there is one lost/ syllable." Because of this loss, she never knows "where or/ how/ to begin." 110

However, Modarres assumes that narration is "a metaphorical, mobile meta-place that allows people to construct [...] multiple selves subject to constant flux" 111 as a way of defending oneself against outside representations. Modarres' project regards narrative spaces that employ more languages to negotiate one's identity as influenced by different narratives. Thus, Gloria

107 https://www.poetryfoundation.org/poetrymagazine/poems/146699/missing-more-than-a-word (accessed June 6, 2018).

108 Erdrich 2018, loc. 211.

109 Jane Staffort, Colonial Literature and the Native Author: Indigeneity and Empire (Cham, Switzerland: Palgrave Macmillan, 2016), 158-159.

110 Erdrich 2018, loc. 2992-3033.

111 Modarres, 2018, 8. 
Anzaldúa insists on her right to speak many languages ("Standard English; Working class and slang English; Standard Spanish; Standard Mexican Spanish; North Mexican Spanish dialect; Chicano Spanish, Tex Mex; and Pachuco" ${ }^{112}$ ) as a fight against the narratives of exclusion. Similarly, in "Conflict Resolution for Holy Beings" Joy Harjo says: "We speak together with this trade language of English, [which] enables us to speak across many language boundaries," 113 suggesting that this enforced language should be subversively used. As Owens says, heteroglossia is a precondition for every literary expression, ${ }^{114}$ which, as a decolonizing means, in its ironical mimicry ${ }^{115}$ should satisfy the dominant culture's reading and publishing expectations while relating tribal realities. ${ }^{116}$ Thus, in Blue Marrow, Louise Bernicle Halfe uses the form of Christian confession to invoke the spiritual rape and reverse it into a hundred pages long healing ceremony that combines English and Cree: "Forgive me father, I have sinned I have hauled thesel tongues of iskwêwak since 1492. I no longer know/ which of me speaks." 117 In "38" Long Soldier tells a story about 38 Dakota men who President Lincoln ordered hanged on "the day after Christmas" 1862, in "the same week" Emancipation Proclamation was signed. To underline the hypocrisy of the civilizers who, while fighting for their rights disregard the others, Long Soldier disciplines her language after the English convention: "Here, the sentence will be respected./ I will compose each sentence with care, by minding what the rules of writing dictate./ For example, all sentences will begin with capital letters." 118 Therefore, what our eyes recognize as poetry is, actually, a way of reinventing the colonizer's language ${ }^{119}$ to destabilize dominant stories and assert the sovereignty of one's voice. ${ }^{120}$ This "frontier

112 Qt. in Ibid., 40.

113 https://www.poetryfoundation.org/poems/141847/conflict-resolution-for-holy-beings (accessed May 20, 2018).

114 Owens 1998, 26.

115 Cf. Homi Bhabha, "Of Mimicry and Man: The Ambivalence of Colonial Discourse," October, Vol. 28, Discipleship: A Special Issue on Psychoanalysis (Spring, 1984), pp. 125-133, http://www.jstor.org/ stable/778467 (accessed January 20, 2021).

116 Cf. James Ruppert, ,Mediation in Contemporary Native American Writing,“ Native American Perspectives on Literature and History, ed. Allan Velie (Norman-London: University of Oklahoma Press, 1995), 7-21.

117 Louise Bernice Halfe, Blue Marrow (Regina: Coteau, 2005), 30.

118 Erdrich 2018, loc. 490.

119 Cf. Gloria Bird and Joy Harjo, Reinventing the Enemy's Language: Contemporary Native Women's Writing of North America (New York, NY: W.W. Norton \& Company, 1997).

120 Cf. Louis Owens, Other Destinies: Understanding the American Indian Novel (Norman-London: University of Oklahoma Press, 1992), 167-191. 
writing" ${ }^{21}$ is also unhomely. While appearing in a familiar form, it voices uncomfortable truths.

\section{Crossing borders}

David Morley argues that "spatial purification," 122 separation of nations by borders and reservations, has inflicted numerous metaphorical borders. Isabel Quintana Wulf agrees that "[b]orders constitute one of the most powerful ways of imagining and enforcing national geographies," 123 by the use of genealogical narratives as tools of inclusion and exclusion, such as the anxiety about economic issues which has intensified border control for the entries of undesirable subjects. The states' borders disturbed internal cohesion within the Indigenous sovereign nations, allowing for the concepts of Native Americans, Alaskans, First Nations, and Chicana/o. While nations are contained within reservations in which they partially practice their sovereignty, they cannot sustain themselves, which makes their members move out searching for employment. As a social construct, the border is also mobile and "shapes human interaction in unexpected places, an ideological process that is absorbed into the national imaginary until it appears as common sense, unquestioned and inherently true," ${ }^{24}$ supporting the "sense of otherness and social illegitimacy." 125

While allowing the examination of enforced mechanisms of exclusion, the border crossing is also a possibility for cultural interaction. Gunn Allen understands reservation borders as signifying "freedom of movement for Native peoples," who "will retain their 'indianness' while participating in global society." 126 Thus, Jan Bourdeau Waboose (Ojibwe) develops "A Memory of Childhood" into a dialogue between a "blue-eyed girl" with "golden hair" and a tribal girl who lives "across the river" in the "Mission Indian Reserve." The reservation girl likes "to follow the railroad tracks across the bridge" leading out of the reservation and to "sing songs my

121 Owens 1998, 26.

122 Morley 2000, 145.

123 Isabel Quintana Wulf, The Underside of Borders: Reading Chican@ and Native American Literature at the Turn of the Twenty-first Century, dissertation (Urbana-Champaign: University of Illinois, 2013), 8.

124 Ibid., 29.

125 Ibid., 45-46.

126 Paula Gunn Allen, Off the Reservation: Reflections on Boundary-Busting, Border-Crossing, Loose Canons (Boston: Beacon, 1998), 6. 
Grandmother taught me, and sometimes I forget how/ far I've come." This induces a meeting with a white girl who starts asking questions: "Where do you live? [...] Isn't that where the Indians live? [...] Are you allowed on this side of the river?" Although these suggest trespassing, there are no "signs that tell me I should not be there," thinks the Indian girl. The white girl assumes that the line that separates the two communities is invisible, suggesting: "Maybe I'm not allowed to cross the bridge over to this side." Neither of the girls knows the rule. They shrug shoulders, "look at each other for a long time," and then combat the prejudice: "I begin to sing. She hums./ And we walk over the bridge along the railroad tracks to my side of the river."127

"The River on Our Face," by Emmy Pérez (Chicana), is illustrative of Gloria Anzaldúa's call in Borderlands to imagine a world without borders, by not only referring to current geopolitical discussions but also by drawing from indigenous ontology in which borders cannot exist. ${ }^{128}$ The poem structures around the Rio Grande, called the crystal frontier, layered with the absurd politics and violence-'The young border patrol officer/ flashes sirens daily/ lifts his gun [...] Relatives/ disappear/ die detained [...] In Ciudad Juárez, a mother hoped/ her missing daughter/ married a rich American [...] Constant helicopters." When these images are removed, the river becomes a tool of inclusion, the place where many peoples and languages meet, just as Spanish words intersect English in the poem. Therefore, the river is a source of life, because its water infuses flora, fauna, and peoples surrounding it. Thus "[t]his river/ at its mouth/ at its source/ With you at its source/ its sources/ With you at the snow/ the evergreens," 129 is reconsidered as a vital possibility of unification instead of a political unit of separation.

Contrary to the conventional expectations that the indigenous are static and centered on one locality, they often choose international mobility. "Vancouver Airport, Gate B20," by Tenille Campbell (Dene, Métis), opens with the line "I'm coming home leaving home finding home" to evoke the transitory position of the young person who has just left home and is about to take up a new place outside the reservation and Canada. She is at the airport, at the "Canadian departures." This place is significant because it presents both the border, an artificial separation line between the peoples,

127 Maracle and Laronde 2000, 137.

128 Gloria Anzaldúa, Borderlands/La Frontera-The New Mestiza (San Francisco: Aunt Lute, 1987).

129 https://www.poetryfoundation.org/poems/91471/the-river-on-our-face (accessed September 2, 2018). 
and a possibility, i.e. her exist from one world and entrance into another. Being "the anonymous of the airports," a no man's land, it is not a sacred place because it lacks a story. Yet, she creates the story of it. She initially wonders where she is going and what she is doing. She is off for something different, yet we do not know what because the new home is not suggested. Concurrently, the home she has left is clearly described: it is north in the Saskatchewan bush, containing a name, a house, reserve, mother, and father. It is a place where she is hugged, where she laughs, and she misses it immensely, which she confirms by repeating: "missing you missing home missing us." However, she still feeds her body with the food from this place -"a coffee shop mocha" and "an egg mimosa"-partaking thus in the physical exchange with this world and making it her own. She is also typing - "the glow of the laptop flickers shadows across my face" 130 - suggesting that what she types is going into the ether and might have global consequences.

Although tribal hermeneutics of communitism appears as relating to specific cultures, it is inclusive and transcends Indigenous communities, "seek[ing] to embrace the entire created order, including plants, animals, Mother Earth herself." 131 Thus, we would essentialize Indigenous poetry if we overlook its agency in the global and trans-indigenous world. ${ }^{132}$ For example, Leslie Marmon Silko's "Prayer to the Pacific" demonstrates how Laguna have come from China-"where ocean herself was born"-and crossed the ocean on the back of turtles " $[t]$ hirty thousand years ago." While the lyrical persona performs a ritual to respect the fertile rain coming from the west, she also gestures that peoples are connected on the ocean's two sides. Morley comments that "the idea of postmodernity" involves "our supposedly de-territorialised culture of 'homelessness,' in which home becomes "a phantasmagoric place, to the extent that electronic media [...] allow the radical intrusion of distant events into the space of domesticity." ${ }^{133}$ In other words, as we free ourselves from spatial identification, we become a part of an alternative cyber community. Concurrently, while globalization threatens the indigenous cultures' integrity, it also provides new channels for

130 Allison Adelle Hedgecoke, ed., Sing (Tucson: The University of Arizona Press, 2011), 259.

131 Weaver 2001, 303.

132 Cf. Jace Weaver and Scott Richard Lyons, eds., The World, the Text, and the Indian: Global Dimensions of Native American Literature (Albany: Sunny, 2017).

133 Morley 2000, 1-9. 
creating important alliances for addressing the effects of settler-colonialism across the globe. ${ }^{134}$ Clifford also notices a possibility of "transnational alliances currently being forged by Fourth World peoples [...] [u]nited by similar claims to "firstness' on the land and by common histories of decimation and marginality." 135 Stewart-Harawira advocates that indigenous peoples should work together towards "a saner, truly sustainable, inclusive, socially just and spiritually informed framework for our collective global existence." ${ }^{136}$ The recent introduction of the term "Indigenous peoples," L.T. Smith explains, "has enabled the collective voices of colonized people to be expressed strategically in the international arena. It has also been an umbrella enabling communities and peoples to come together, transcending their own colonized contexts and experiences, in order to learn, share, plan, organize and struggle collectively for self-determination on the global and local stages." 137

This new sharing community achievable through the Indigenous global citizenship project will help heal the historical pain. Thus, in her poem "Truganinny," Wendy Rose (Hopy) recognizes the pain of a Tasmanian Truganinny, who was the last of her tribe and who saw the stuffed body of her husband mounted in a museum. Rose informs that Truganinny's "dying wish [was to] be buried [so that] her body [is not] subjected to/ the same indignities." Rose takes over Truganinny's dying voice and invites the listener to come closer, "for little is left/ of this tongue/ and what I am saying/ is important./ I am the last one." She has witnessed the death of her nation -"daughters dead/ their mouths empty and round/ their breathing stopped/ their eyes gone gray"-and fears that she will also be deprived of her reality and her right to speak. When the last woman says "[t]ake my hand/ black into black," so that the other black hand may help her go back to "the Dream," her home, she also promises: "Do no leave me/ for I would speak, / I would sing/ one more song." 138

134 Cf. Stewart-Harawira 2005, Smith 2015, Smith, 2007.

135 Clifford 1994, 309.

136 Stewart-Harawira 2005, 6.

137 Smith 2007, 7.

138 Duane Niatum, ed., Harper's Anthology of 20th Century Native American Poetry (New York: HarperCollins, 1988), 240-241. 


\section{Conclusion}

Home in the cultures Indigenous to North America represents an inhomogeneous space that is both physical and representational, being formatted as a house and a homeland, but also as a social order or a cultural formation. This conceptualization comes from the indigenous circular cosmogony which understands the oneness of existence and, therefore, that a person stems from the community and is inextricably related to the storied cultural place. Notwithstanding, dispersion of the concept necessarily resulted from the prolonged and racialized experience of homelessness brought about with colonization. Dispossession of home, as a measure of being, involves ontological, existential, and epistemological denials, as reflected in a series of reifications of the Indigenous subject and its enforced historicity. Therefore, unlike the modernist tendency to leave home constraints, the Indigenous home is a place of celebration and must be reclaimed for national betterment and self-determination. Moreover, contrary to the conventional understanding of the Indigenous as static, around the world today they are recognizing the momentum, brought about by the globalization and digitalization, which, although seemingly detrimental to cultural authenticity, offers new channels and tools for sharing decolonizing language and healing resources and, thus, for claiming a new global recognition, their home on the Earth. 